\title{
PERBANDINGAN ALGORITMA KLASIFIKASI DATA MINING UNTUK PENELUSURAN MINAT CALON MAHASISWA BARU
}

\author{
Budiman $^{1}$, Zatin Niqotaini ${ }^{2}$ \\ ${ }^{1,2}$ Sistem Informasi, Fakultas Teknologi dan Informatika \\ Universitas Informatika dan Bisnis Indonesia \\ E-mail: *1udiman1982@gmail.com, ${ }^{2}$ zatinniqotaini@unibi.ac.id
}

\begin{abstract}
Abstrak
Masa pandemi AMIK HASS mengalami kesulitan dalam menentukan calon mahasiswa baru. Sehingga dalam upaya menarik minat masyarakat Bagian Marketing telah menerapkan beberapa strategi dalam menarik minat calon mahasiswa untuk bergabung menjadi mahasiswa baru. Teknik data mining yang digunakan dalam memprediksi adalah klasifikasi di antaranya Nä̈ve Bayes, Decision Tree J48, dan K-Nearest Neighbor. Tujuan dari penelitian ini adalah melakukan analisis perbandingan terhadap algoritma klasifikasi data mining dengan menggunakan tools WEKA. Metode yang yang digunakan dalam penelitian ini, menggunakan CRISP-DM. Data set yang digunakan ketiga klasifikasi sebanyak 5934 record dengan mode test percentage split yaitu $70 \%$ sebanyak 4154 sebagai data training dan 30\% sebanyak 1780 data sebagai data testing. Berdasarkan hasil pengujian terhadap ketiga model klasifikasi maka nilai accuracy tertinggi diperoleh pada klasifikasi Decision Tree J48 yang memperoleh nilai 90,3\%. Sedangkan klasifikasi $K$-Nearest Neighbor memiliki accuracy lebih rendah yaitu 87,52\% dan klasifikasi Nä̈ve Bayes memiliki accuracy yaitu 87,24\%. Perbandingan hasil pengujian AUROC Decision Tree J48 memiliki nilai tertinggi 0,9654 sedangkan hasil Nä̈ve Bayes yaitu 0,9461 dan hasil $K$ Nearest Neighbor yaitu 0,9343. Ketiga klasifikasi memiliki nilai AUC diatas 0,90 masuk ke dalam kategori Excellent Classification.
\end{abstract}

Kata kunci: Data Mining, Klasifikasi, Nä̈ve Bayes, Decision Tree J48, K-Nearest Neighbor

\begin{abstract}
During the pandemic period, AMIK HASS faces difficulties to determine new student candidates. In order to attract public interest, the Marketing Department has implemented several strategies to attract prospective students to become new students. The data mining technique used in predicting is a classification that includes Nä̈ve Bayes, J48 Decision Tree, and K-Nearest Neighbor. This study aims to perform a comparative analysis of data mining classification algorithms using WEKA tools. The method used in this study is CRISP-DM. The dataset used by the three classifications is 5.934 records with split mode, the percentage of testing is $70 \%$ as much as 4154 as training data and $30 \%$ as much as 1780 data as test data. Based on the test results on the three classification models, the highest accuracy value is obtained in the J48 Decision Tree classification, which has a value of $90.3 \%$. While the K-Nearest Neighbor classification has a lower accuracy of $87.52 \%$ and the Nä̈ve Bayes classification has an accuracy of $87.24 \%$. The comparison of the AUROC J48 Decision Tree test results has the highest value of 0.9654 while the Naïve Bayes results are 0.9461 and the K-Nearest Neighbor results are 0.9343. The three classifications with ABK scores above 0.90 are included in the excellent classification category.
\end{abstract}

Keywords: Data Mining, Classification, Nä̈ve Bayes, J48 Decision Tree, K-Nearest Neighbor 


\section{PENDAHULUAN}

Perkembangan teknologi informasi saat ini semakin pesat, seiiring dengan perkembangan tersebut maka transaksi data meningkat dalam hitungan detik sehingga volume data setiap tahun tumbuh dengan berbagai jenis data yang tersebar. Komputerisasi masyarakat saat ini secara substansial telah meningkatkan kemampuan untuk menghasilkan dan mengumpulkan data dari berbagai sumber untuk dikonsumsi oleh semua kalangan. Bahkan Big Data telah membanjiri hampir setiap aspek kehidupan masyarakat.

Pertumbuhan data yang eksplosif telah tersimpan, sementara data telah menghasilkan kebutuhan yang mendesak untuk teknik baru dan tools otomatis yang dapat membantu dengan cerdas dalam mentransformasikan data berjumlah besar menjadi informasi yang bermanfaat dan pengetahuan. Hal ini menyebabkan berkembangnya ilmu komputer yang disebut data mining dengan berbagai aplikasinya.

Perkembangan data mining saat ini merupakan perangkat teknologi informasi yang sangat kuat digunakan dalam dunia bisnis yang kompetitif, terutama ketika masyarakat memasuki era Big Data. Dalam beberapa tahun terakhir, aplikasi data mining telah menjadi strategi bisnis yang penting bagi kebanyakan perusahaan yang ingin menarik pelanggan baru dan mempertahankan pelanggan yang sudah ada. Sedangkan data mining dalam dunia pendidikan telah banyak diterapkan perguruan tinggi dalam melakukan prediksi terhadap mahasiswa diantaranya mengukur kinerja mahasiswa dalam pembelajaran, kelulusan tepat waktu, drop out, penerimaan mahasiswa baru dan lain-lain. Dampak Covid-19 membawa dampak perubahan yang sangat besar terhadap kehidupan masyarakat, penggunaan teknologi informasi dapat dijadikan solusi untuk mengatasi masalah kehidupan seperti Work From Home dan School From Home.

AMIK HASS merupakan perguruan tinggi swasta di kota, dalam melaksanakan tridharma perguruan tinggi mahasiswa merupakan faktor utama dalam menentukan kelangsungan dan keberadaan sebuah perguruan tinggi, pada masa pandemi AMIK HASS mengalami kesulitan dalam menentukan calon mahasiswa baru. Sehingga dalam upaya menarik minat masyarakat Bagian Marketing telah menerapkan beberapa strategi dalam menarik minat calon mahasiswa untuk bergabung menjadi mahasiswa baru. Penelusuran potensi dan minat merupakan salah satu strategi yang digunakan oleh Bagian Marketing dalam menentukan target siswa SMA/SMK/MA yang akan menjadi calon mahasiswa baru. Melalui data penelusuran potensi dan minat, Bagian Marketing harus memiliki pola atau aturan dalam menentukan potensi calon mahasiswa baru sehingga membutuhkan waktu yang lama. Penelitian dengan kajian data mining telah banyak dilakukan oleh para peneliti, di bawah ini merupakan penelitian terdahulu yang paling relevan telah dilakukan oleh peneliti dengan kajian klasifikasi data mining.

Penelitian pertama dilakukan oleh Rony Setiawan. Peneliti melakukan penelitian penerapan data mining menggunakan algoritma K-Means Clustering untuk menentukan strategi promosi mahasiswa baru. Penelitian ini membahas tentang penerapan data mining, menggunakan algoritma $K$-Means Clustering untuk menghasilkan profil yang memiliki kemiripan atribut yang sama. Metode yang digunakan adalah CRISP- DM dengan melalui proses business understanding, data understanding, data preparation, modeling, evaluation dan deployment. Atribut yang digunakan usia, agama, status ujian, kelulusan, registrasi, kelamin, gelombang pendaftaran, gelombang registrasi, Nilai Tes, Jurusan, program studi, sumber informasi, asal kota, lokasi kampus, pekerjaan orang tua, jenis sekolah, pembayaran uang registrasi. Menghasilkan jumlah kluster $4(\mathrm{k}=4)$ dengan cluster pertama 17007 calon mahasiswa, cluster kedua sebanyak 83 calon mahasiswa, cluster ketiga sebanyak 12919 calon mahasiswa dan 
cluster keempat sebanyak 356 calon Mehta. Peneliti melakukan penelitian prediksi mahasiswa.[1] kinerja akademik mahasiswa dengan

Penelitian kedua dilakukan Norzam Yahya menggunakan Teknik data mining. Algoritma dan Arief Jananto, peneliti melakukan klasifikasi yang digunakan yaitu Nä̈ve Bayes, penelitian komparasi kinerja algoritma C4.5 dan Decision Tree, Random-Forest, JRip dan Nä̈ve Bayes untuk prediksi kegiatan ZeroR. Hasil yang diperoleh dari penelitian penerimaan mahasiswa baru, didapatkan hasil tersebut bahwa algoritma klasifikasi seperti One tertinggi pada pengujian dengan data training Rule, Joint Reserve Intelligence Program dan sebanyak 2133 dan data testing sebanyak 533 Decision Tree memiliki tingkat accuracy lebih yaitu algoritma C45 memiliki nilai accuracy dari 80\% untuk memprediksi mahasiswa.[5] lebih tinggi sebesar $88.74 \%$ dibandingkan Penelitian keenam dilakukan Sri algoritma Nä̈ve Bayes yang memiliki accuracy Widaningsih. Peneliti melakukan penelitian sebesar $87.24 \%$.[2] perbandingan metode data mining untuk

Penelitian ketiga dilakukan Vivek Raj S. prediksi nilai dan waktu kelulusan mahasiswa N. dan S. K. Manivannan, peneliti melakukan prodi teknik informatika dengan algoritma penelitian memprediksi dan mengidentifikasi C4.5, Nä̈ve Bayes, K-Nearest Neighbor dan mahasiswa yang cenderung gagal dalam Support Vector Machine. Variabel-variabel menyelesaikan ujian. Algoritma Machine prediktor terdiri dari jenis kelamin dan indeks Learning yang digunakan adalah Rep Tree, Jrip, prestasi dari semester 3 hingga 6. Hasil akhir Random Forest, Random Tree, Nä̈ve Bayes. dari keempat algoritma tersebut diperoleh Hasil yang diperoleh dari semua algoritma bahwa algoritma Nä̈ve Bayes merupakan klasifikasi hanya Rep Tree yang memiliki nilai algoritma terbaik untuk memprediksi kelulusan precision dan $f$ score yang signifikan. Algoritma mahasiswa yang tepat waktu dan IPK $\geq 3$ Random Forest keseluruhan memiliki nilai dengan nilai accuracy (76,79\%), error accuracy 66,14\% dan $f$ score sebesar 0,482 (23,17\%), dan Area Under Curve (0,850).[6] lebih rendah dari 0,5. Algoritma Naives Bayes Penelitian ketujuh dilakukan Azahari, keseluruhan memiliki nilai accuracy 62,20\% Yulindawati, Dewi Rosita dan Syamsuddin tapi memiliki $f$ score hanya 0,429.[3] Mallala. Peneliti melakukan penelitian

Penelitian keempat dilakukan Er. komparasi data mining Nä̈ve Bayes dan Neural AmlanJyoti Baruah, dkk. Peneliti melakukan Network memprediksi masa studi mahasiswa penelitian analisis komparasi perbedaan S1. Atribut yang digunakan yaitu, umur saat algoritma klasifikasi berdasarkan kinerja masuk kuliah, klasifikasi kota asal Sekolah akademik mahasiswa menggunakan tools Menengah Atas, pekerjaan ayah, program studi, WEKA. Algoritma klasifikasi yang digunakan kelas, jumlah saudara, dan Indeks Prestasi diantaranya J48, Random Forest, Rap Tree, Kumulatif(IPK). Hasil penelitian menunjukkan LMT, Nä̈ve Bayes, BayesNet dan PART dengan banyaknya kelemahan dari hasil prediksi Naive kuesionar pada mahasiswa tingkat akhir. Bayes dikarenakan tingkat accuracy Berdasarkan hasil percobaan $J 48$ memiliki kevalidannya tergolong tidak terlalu tinggi. accuracy 85,81\%, Random Forest memiliki Sedangkan accuracy prediksi Neural Network accuracy $100 \%$, Rap Tree memiliki accuracy adalah 72,58\%, sehingga metode alternatif 68\%, LMT memiliki accuracy 80\%, Nä̈ve inilah yang lebih baik.[7]

Bayes memiliki accuracy 78\%, BayesNet Penelitian kedelapan dilakukan Safitri memiliki accuracy 70\%, PART memiliki linawati, Rizky Ade Safitri, Ahmad Rifqy accuracy $90 \%$.[4]

Alfiyan, Witriana Endah Pangesti dan Monikka

Penelitian kelima dilakukan Nidhi, Nur Winnarto. Peneliti melakukan penelitian Mukesh Kumar, Nandini Nayar, dan Gaurav perbandingan algoritma klasifikasi Naive Bayes 
dan Support Vector Machine pada studi kasus digunakan dalam memprediksi adalah pemberian penerima beasiswa PPA. klasifikasi di antaranya Nä̈ve Bayes, Decision Berdasarkan hasil komparasi antara algoritma Tree J48, dan K-Nearest Neighbor. Tujuan dari Naive Bayes dan Support Vector Machine yang penelitian ini adalah melakukan analisis dilakukan untuk mengklasifikasikan nilai perbandingan terhadap algoritma klasifikasi accuracy tertinggi dengan 5 variabel dan jumlah data mining dengan menggunakan tools data sebesar 122 dapat disimpulkan bahwa WEKA, sehingga peneliti dapat mengetahui algoritma Naive Bayes memiliki tingkat efektifitas algoritma klasifikasi data mining accuracy lebih tinggi yaitu 90,90\% yang terbaik terhadap data set penelusuran dibandingkan dengan metode Support Vector potensi dan minat calon mahasiswa baru.

Machine yaitu 89.25\%.[8]

Penelitian kesembilan dilakukan Hermanto, Ali Mustopa dan Antonius Yadi Kuntoro. Peneliti melakukan penelitian algoritma klasifikasi Nä̈ve Bayes dan Support Vector Machine dalam layanan komplain mahasiswa. Hasil Penelitian diperoleh algoritma Support Vector Machine memiliki nilai accuracy tertinggi dibanding Naïve Bayes. Nilai $\mathrm{AUC}=0,922$. untuk metode Support vector Machine dengan menggunakan data set sisfo akademik mahasiswa (students.bsi.ac.id) memiliki $84,45 \%$, dari algoritma Nä̈ve Bayes memiliki tingkat accuracy sekitar $69.75 \%$ dan nilai $\mathrm{AUC}=0,679 .[9]$

Penelitian kesepuluh dilakukan Budiman, dkk. Peneliti melakukan penelitian implementasi datamining menggunakan algoritma Nä̈ve Bayes dan Decision Tree J48 dalam menentukan pemilihan konsentrasi. Hasil yang diperoleh terdapat 4 pola atau pattern yang terbentuk untuk menentukan pemilihan konsentrasi, sehingga bagian akademik dapat membantu mahasiswa dalam menentukan pemilihan konsentrasi. Nilai accuracy tertinggi diperoleh pada klasifikasi Nä̈ve Bayes yang memperoleh nilai $71,4 \%$. Sedangkan klasifikasi Decision Tree J48 memiliki accuracy lebih rendah yaitu 64,3\%.[10]

Berdasarkan permasalahan di atas dan penelitian terdahulu maka diperlukan aturan atau pola dalam memprediksi calon mahasiswa baru melalui penelusuran potensi dan minat. Peneliti tertarik untuk melakukan penelitian data mining, adapun teknik data mining yang

\section{METODE PENELITIAN}

Metode yang dilakukan dalam penelitian merujuk pada metode yang dikemukakan Larose (2015) terlihat pada gambar 1 yaitu data mining memiliki enam fase CRISP-DM (Cross Industry Standard Process for Data Mining) sebagai berikut:[11,12,13]

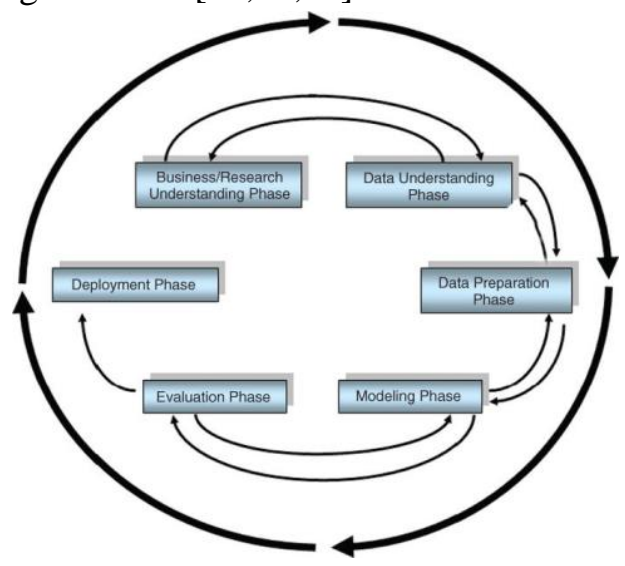

Gambar 1 Metode Cross Industry Standard Process for Data Mining atau CRISP-DM

a. Fase Pemahaman Bisnis (Business Understanding Phase) akan dilakukan pemahaman tujuan bisnis, menilai situasi, dan menentukan tujuan data mining. Berdasarkan pemahaman tersebut, kemudian menterjemahkan pengetahuan ke dalam pendefinisian masalah data mining. Selanjutnya akan ditentukan strategi untuk mencapai tujuan tersebut.

b. Fase Pemahaman Data (Data Understanding Phase) akan dilakukan pengumpulan data awal, mendeskripsikan data, mengeksplorasi data dan memverfikasi kualitas data. Sehingga akan 
terdeteksi bagian yang menarik dari data yang dapat digunakan untuk menggali informasi yang tersembunyi.

c. Fase Pengolahan Data (Data Preparation Phase) akan dilakukan pendeskripsian data set, memilih data, mengintegrasikan data dan membangun data. Proses ini juga mencakup pemilihan tabel, record dan atribut data termasuk pembersihan dan transformasi data. Sehingga akan terbentuk data set akhir sebagai data mentah yang akan diproses pada fase pemodelan.

d. Fase Pemodelan (Modeling Phase) akan dilakukan pemilihan teknik pemodelan, membangun model dan menilai model. Saat membangun model dari data set yang digunakan, penelitian ini menggunakan mode test percentage split yaitu membagi dua bagian dari data set sebagai data training dan data testing yang akan diujikan terhadap model yang telah dibentuk.

e. Fase Evaluasi (Evaluation Phase) akan dilakukan jika model sudah terbentuk dengan harapan memiliki kualitas yang baik dilihat dari sudut pandang analisa data. Adapun tahapan yang akan dilakukan yaitu evaluasi hasil, meninjau proses dan menentukan langkah selanjutnya. Evaluasi yang dilakukan terhadap keefektifan dan kualitas data model sebelum digunakan dan menentukan apakah model dapat mencapai tujuan berdasarkan fase awal Business Understanding yang ditetapkan. Sehingga dapat ditentukan apakah ada masalah bisnis yang belum ditentukan.

f. Fase Penyebaran (Deployment Phase), tahap ini merupakan pengetahuan atau informasi yang telah diperoleh akan diatur dan dipresentasikan dalam bentuk khusus sehingga dapat digunakan oleh pengguna.

\section{HASIL DAN PEMBAHASAN}

\subsection{Fase Pemahaman Bisnis (Business Understanding Phase)}

Penelitian ini bertujuan untuk melakukan analisis perbandingan kinerja algoritma klasifikasi diantaranya Nä̈ve Bayes, Decision Tree dan K-Nearest Neighbor terhadap data set penelusuran potensi dan minat calon mahasiswa baru serta mengidentifikasi pola-pola yang terbentuk dari data masa lampau. Sehingga dalam upaya menarik minat masyarakat Bagian Marketing dapat menerapkan strategi pengambilan keputusan dalam menarik minat calon mahasiswa untuk bergabung menjadi mahasiswa baru pada masa pandemi Covid-19.

Tujuan Bisnis yaitu meningkat jumlah pendaftar calon mahasiswa baru. Penilaian Situasi, AMIK HASS Bandung merupakan perguruan tinggi di Kota Bandung yang memiliki Program Studi Manajemen Informatika terbagi menjadi empat konsentrasi yaitu Komputer Administrasi, Komputerisasi Akuntansi, Multimedia dan E-Commerce. Tujuan Data Mining yaitu menentukan strategi marketing sehingga dapat menenukan profil yang bertujuan untuk mengetahui profil calon mahasiswa baru yang melakukan pendaftaran di AMIK HASS Bandung dan mengetahui strategi marketing berdasarkan pada profil calon mahasiswa baru.

\subsection{Fase Pemahaman Data (Data Understanding Phase)}

Pada fase pemahaman data terdiri dari beberapa proses diantaranya pengumpulan data awal, deskripsi data, eksplorasi data dan verifikasi kualitas data. Proses pengumpulan data bertujuan untuk mempelajari struktur data pada Bagian Marketing melalui penelusuran potensi dan minat calon mahasiswa baru terlihat pada Tabel 1, selanjutnya menentukan atribut yang akan digunakan dalam proses data mining. Proses deskripsi data bertujuan untuk menganalisis sumber data awal yang diperoleh dari database Bagian Marketing. Sehingga dapat 
menentukan atribut yang akan diproses dalam proses data mining tidak ada kesalahan, yaitu data mining. melalui langkah sebagai berikut: memastikan

Tabel 1 Atribut Penelusuran Potensi dan Minat Calon Mahasiswa Baru

\begin{tabular}{|c|c|c|}
\hline No & Atr & an \\
\hline 1. & $\begin{array}{l}\text { Tanggal } \\
\text { Pendaftaran }\end{array}$ & $\begin{array}{l}\text { Tanggal pendaftaran } \\
\text { calon mahasiswa baru di } \\
\text { AMIK HASS Bandung }\end{array}$ \\
\hline 2. & $\mathrm{Nc}$ & $\begin{array}{l}\text { Nama calon mahasiswa } \\
\text { baru }\end{array}$ \\
\hline 3. & $\begin{array}{l}\text { Jenis } \\
\text { Kelamin }\end{array}$ & $\begin{array}{l}\text { Jenis kelamin calon } \\
\text { mahasiswa baru }\end{array}$ \\
\hline 4. & $\begin{array}{l}\text { Tempat } \\
\text { Lahir }\end{array}$ & $\begin{array}{l}\text { Tempat tanggal lahir } \\
\text { calon mahasiswa baru }\end{array}$ \\
\hline & $\begin{array}{l}\text { Tanggal } \\
\text { Lahir }\end{array}$ & $\begin{array}{l}\text { Tanggal lahir calon } \\
\text { mahasiswa baru }\end{array}$ \\
\hline & Alamat & $\begin{array}{l}\text { Alamat calon mahasiswa } \\
\text { baru }\end{array}$ \\
\hline & Tele & $\begin{array}{ll}\text { Telepon } & \text { calon } \\
\text { mahasiswa baru }\end{array}$ \\
\hline & $\begin{array}{l}\text { Asal } \\
\text { Sekolah }\end{array}$ & $\begin{array}{l}\text { Asal sekolah calon } \\
\text { mahasiswa baru }\end{array}$ \\
\hline & Jurusan & $\begin{array}{l}\text { Jurusan yang diambil } \\
\text { calon mahasiswa baru } \\
\text { pada saat sekolah } \\
\text { terakhir }\end{array}$ \\
\hline & $\begin{array}{l}\text { Nama } \\
\text { Orang Tua }\end{array}$ & $\begin{array}{l}\text { Nama orang tua calon } \\
\text { mahasiswa baru }\end{array}$ \\
\hline & $\begin{array}{l}\text { Pekerjaan } \\
\text { Orang Tua }\end{array}$ & $\begin{array}{l}\text { Pekerjaan orang tua } \\
\text { calon mahasiswa baru }\end{array}$ \\
\hline & Peminatan & $\begin{array}{l}\text { Jurusan yang akan dipilih } \\
\text { calon mahasiswa baru } \\
\text { setelah lulus dari sekolah }\end{array}$ \\
\hline & $\begin{array}{l}\text { Minat } \\
\text { Kuliah }\end{array}$ & $\begin{array}{l}\text { Minat calon mahasiswa } \\
\text { baru untuk kuliah di } \\
\text { AMIK HASS Bandung }\end{array}$ \\
\hline
\end{tabular}

Proses eksplorasi data bertujuan untuk menentukan Sumber data yang digunakan dalam penelitian ini adalah data penelusuran potensi dan minat calon mahasiswa pada tahun 2013-2018 pada Bagian Marketing AMIK HASS Bandung

Proses verifikasi kualitas data bertujuan untuk memastikan data yang digunakan pada sumber record terisi dengan data dan tidak ada anomaly data. Jika terjadi data kosong maka sesuai dengan ketentuan record tersebut akan dihapus. Kemudian memastikan tidak ada duplikasi data, jika terdapat duplikasi maka salah satu data akan dihapus.

\subsection{Fase Pengolahan Data (Data Preparation Phase)}

Pada fase pengolahan data dilakukan pada data set penelusuran potensi dan minat calon mahasiswa baru sebanyak 6866 record dengan 13 atribut. Tahap yang dilakukan pada proses meliputi pemilihan data, pembersihan data dan transformasi data. Proses pemilihan data ini dilakukan untuk memilih atribut yang akan digunakan pada pembentukan model algoritma klasifikasi. Proses pembersihan data dilakukan untuk proses cleaning dari data awal sebanyak 6866 record semuanya tidak utuh atau lengkap, dimana data yang tidak lengkap dibuang atau tidak digunakan. Sehingga yang tersisa sebanyak 5934 record. Sedangkan pada proses transformasi data terdapat beberapa atribut yang dapat disederhanakan seperti atribut Alamat menjadi atribut Domisili dan atribut Tanggal Pendaftaran menjadi atribut Status. Kemudian dilakukan konversi nilai dari atribut Alamat terhadap atribut Domisili dengan menentukan wilayah tempat tinggal berdasarkan Kota atau Kabupaten. Konversi nilai atribut tanggal pendaftaran terhadap atribut Status pun dilakukan menjadi Daftar atau Tidak Daftar. Nilai atribut Peminatan awalnya berisi data jurusan yang diminati calon mahasiswa baru dikonversi menjadi beberapa kategori diantaranya Komputer, Non Komputer dan Kerja dalam hal ini tidak melanjutkan untuk kuliah.

Tabel 2 dibawah ini merupakan atribut terpilih beserta potongan record yang akan digunakan sebagai data set pengujian terhadap algoritma klasifikasi diantaranya Nä̈ve Bayes, Decision Tree dan K-Nearest Neighbor. 
Tabel 2 Data set Pengujian

\begin{tabular}{|c|c|c|c|c|c|c|c|}
\hline $\begin{array}{l}\text { Asal } \\
\text { Sekolah }\end{array}$ & $\begin{array}{l}\text { Jenis } \\
\text { Kelamin }\end{array}$ & Domisili & Jurusan & $\begin{array}{l}\text { Pekerjaan } \\
\text { Orang } \\
\text { Tua }\end{array}$ & Peminatan & $\begin{array}{l}\text { Minat } \\
\text { Kuliah }\end{array}$ & Status \\
\hline $\begin{array}{l}\text { MA } \\
\text { Hifaz }\end{array}$ & $\mathrm{P}$ & Garut & IPS & Lain-Lain & Komputer & Berminat & Daftar \\
\hline $\begin{array}{l}\text { MAN } \\
\text { Ciparay }\end{array}$ & $\mathrm{P}$ & $\begin{array}{l}\text { Kabupaten } \\
\text { Bandung }\end{array}$ & IPS & Wiraswasta & Komputer & Berminat & Daftar \\
\hline $\begin{array}{l}\text { MAN } \\
\text { Cililin }\end{array}$ & $\mathrm{L}$ & $\begin{array}{l}\text { Bandung } \\
\text { Barat }\end{array}$ & IPA & Wiraswasta & Komputer & Berminat & Daftar \\
\hline $\begin{array}{l}\text { MAN } \\
\text { Subang }\end{array}$ & $\mathrm{L}$ & Subang & IPA & Wiraswasta & $\begin{array}{l}\text { Non } \\
\text { Komputer }\end{array}$ & Berminat & Daftar \\
\hline $\begin{array}{l}\text { SMAN } 1 \\
\text { Ciparay }\end{array}$ & $\mathrm{L}$ & $\begin{array}{l}\text { Kabupaten } \\
\text { Bandung }\end{array}$ & IPA & PNS & Kerja & Berminat & Daftar \\
\hline $\begin{array}{l}\text { SMAN } 1 \\
\text { Serang } \\
\text { Panjang }\end{array}$ & $\mathrm{L}$ & Subang & IPA & $\begin{array}{l}\text { Karyawan } \\
\text { Swasta }\end{array}$ & Komputer & Berminat & Daftar \\
\hline $\begin{array}{l}\text { SMAN } 2 \\
\text { Subang }\end{array}$ & $\mathrm{P}$ & Subang & IPA & Wiraswasta & Komputer & $\begin{array}{l}\text { Tidak } \\
\text { Berminat }\end{array}$ & Daftar \\
\hline $\begin{array}{l}\text { SMAN } 1 \\
\text { Subang }\end{array}$ & $\mathrm{L}$ & Subang & IPA & Wiraswasta & Komputer & Berminat & Daftar \\
\hline $\begin{array}{l}\text { SMA } \\
\text { PGRI } \\
\text { Subang } \\
\end{array}$ & $\mathrm{P}$ & Subang & IPS & $\begin{array}{l}\text { Karyawan } \\
\text { Swasta }\end{array}$ & $\begin{array}{l}\text { Non } \\
\text { Komputer }\end{array}$ & $\begin{array}{l}\text { Tidak } \\
\text { Berminat }\end{array}$ & Daftar \\
\hline $\begin{array}{l}\text { SMA } \\
\text { PGRI } \\
\text { Ciranjang }\end{array}$ & $\mathrm{P}$ & Cianjur & IPA & IRT & Komputer & Berminat & Daftar \\
\hline$\ldots$ & $\ldots$ & $\ldots$ & $\ldots$ & $\ldots$ & $\ldots$ & $\ldots$ & $\ldots$ \\
\hline $\begin{array}{l}\ldots \\
\text { SMA } \\
\text { PGRI } \\
\text { Ciranjang }\end{array}$ & $\begin{array}{l}\ldots \\
P\end{array}$ & $\begin{array}{l}\ldots \\
\text { Cianjur }\end{array}$ & $\begin{array}{l}\ldots \\
\text { IPS }\end{array}$ & $\begin{array}{l}\ldots \\
\text { Wiraswasta }\end{array}$ & $\begin{array}{l}\text {... } \\
\text { Komputer }\end{array}$ & $\begin{array}{l}\ldots \\
\text { Berminat }\end{array}$ & $\begin{array}{l}\text {... } \\
\text { Daftar }\end{array}$ \\
\hline
\end{tabular}


JURNAL NUANSA INFORMATIKA

Volume 15 Nomor 2, Juli 2021
p-ISSN : 1858-3911, e-ISSN : 2614-5405

https://journal.uniku.ac.id/index.php/ilkom

\subsection{Fase Pemodelan (Modeling Phase)}

Penelitian berbentuk pengujian terhadap data penelusuran potensi dan minat calon mahasiswa baru memilih yang diambil dari Bagian Marketing yang dituangkan dalam bentuk tabel. Data tersebut akan dilakukan tiga kali percobaan menggunakan Nä̈ve Bayes[14,10], Decision Tree J48[10,15,16] dan K-Nearest Neighbor[17,18] dengan tools pembelajaran mesin "WEKA" dengan menggunakan mode test percentage split sebesar $70 \%$ sebagai data training dan 30\% sebagai data testing.

Prediksi yang dilakukan dalam penelitian ini adalah menentukan pendaftaran berdasarkan penelusuran potensi dan minat calon mahasiswa baru berikut ini atribut prediksi yang digunakan dalam penelitian ini diantaranya Asal Sekolah, Jenis Kelamin, Jurusan, Pekerjaan Orang Tua, Peminatan, Minat Kuliah dan Status.

\subsection{Fase Evaluasi (Evaluation Phase)}

Pengujian prediksi dilakukan dengan menggunakan tiga teknik klasifikasi yaitu Nä̈ve Bayes dan Decision Tree J48 dan KNearest Neighbor. Data set yang digunakan dalam penelitian ini sebanyak 5934 record dengan mode test percentage split yaitu 70\% atau 4154 data digunakan sebagai data training sebagai pembentukan model dan $30 \%$ atau 1780 data sebagai data testing yang akan diujikan terhadap model yang telah dibentuk.

\section{a. Nä̈ve Bayes}

Gambar 2 merupakan hasil pengujian klasifikasi Nä̈ve Bayes terhadap data training, pengujian dilakukan dengan metode yang sama pada Decision Tree J48 dan K-Nearest Neighbor.

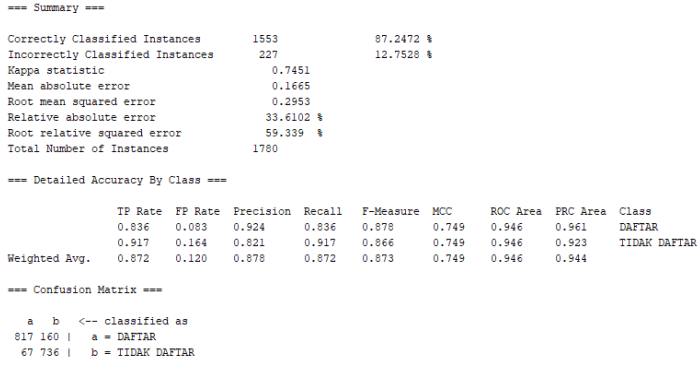

Gambar 2 Hasil Pengujian Nä̈ve Bayes

Pada Gambar 2 menunjukkan hasil pengujian menggunakan klasifikasi Nä̈ve Bayes memiliki tingkat accuracy sebesar $87,24 \%$ atau 1553 instance yang menyatakan rasio prediksi benar dengan keseluruhan data testing yang diujikan, sedangkan mean absolute error sebesar 0,1665. Precision pada kelas Daftar 92,4\% menunjukkan bahwa persentase calon mahasiswa baru yang benar melakukan pendaftaran dari keseluruhan calon mahasiswa baru yang diprediksi melakukan pendaftaran. Kelas Tidak Daftar memiliki Precision sebesar 82,1\% menunjukkan bahwa persentase calon mahasiswa baru yang benar tidak melakukan pendaftaran dari keseluruhan calon mahasiswa baru mahasiswa yang diprediksi tidak melakukan pendaftaran.

Recall untuk kelas Daftar sebesar 83,6\% menunjukkan bahwa persentase calon mahasiswa baru yang diprediksi melakukan pendaftaran dibandingkan keseluruhan calon mahasiswa baru yang sebenarnya melakukan pendaftaran. Sedangkan Recall untuk kelas Tidak daftar sebesar 91,7\% menunjukkan bahwa persentase calon mahasiswa baru yang diprediksi tidak melakukan pendaftaran dibandingkan keseluruhan calon mahasiswa baru yang sebenarnya tidak melakukan pendaftaran.

Confusion Matrix Nä̈ve Bayes, baris pertama terdapat "817 160" menunjukkan bahwa ada instance class Daftar dalam data testing diantaranya 817 benar di prediksi sebagai Daftar dan 160 salah diklasifikasikan sebagai Tidak Daftar. Pada 
Baris kedua terdapat "67 736" menunjukkan bahwa ada instance class Tidak Daftar dalam data testing diantaranya 67 salah diklasifikasi sebagai Daftar dan 736 benar diklasifikasikan Tidak Daftar.

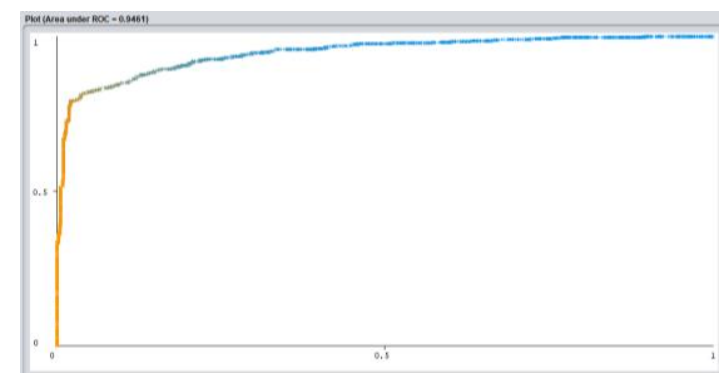

\section{Gambar 3 Area Under ROC}

Gambar 3 menunjukkan Area Under $R O C$ dihitung untuk mengukur perbedaan performansi. Kurva ROC menunjukkan accuracy dan membandingkan klasifikasi secara visual dengan false positive sebagai garis horizontal dan true negative sebagai garis vertical. Berdasarkan hasil pengujian menggunakan pengukuran Nä̈ve Bayes didapatkan hasil AUROC 0,9461.

Gambar 4 menunjukkan hasil prediksi terhadap data testing sebanyak 1780 record setelah model dibentuk menggunakan klasifikasi Nä̈ve Bayes. Sedangkan Waktu yang dibutuhkan dalam test model selama 0,05 detik.

\section{Gambar 4 Hasil Prediksi Klasifikasi}

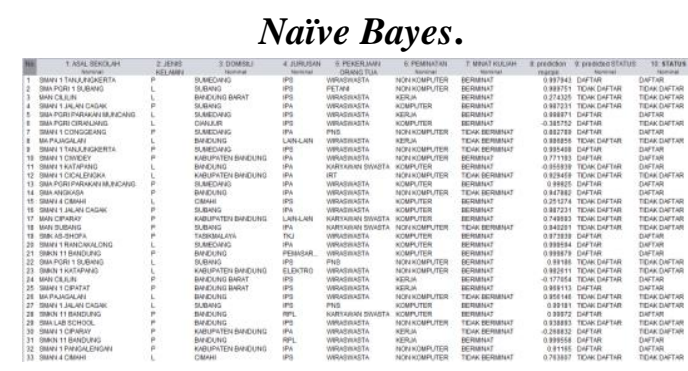

\section{b. Decision Tree $\mathrm{J} 48$}

Gambar 5 merupakan hasil pengujian klasifikasi Decision Tree J48 terhadap data training, pengujian dilakukan dengan metode yang sama pada Nä̈ve Bayes dan KNearet Neighbor.

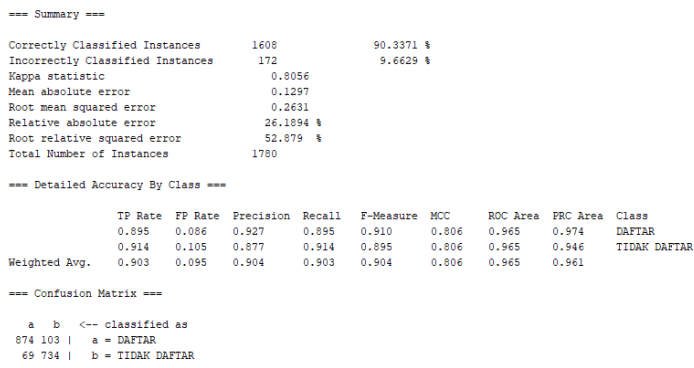

\section{Gambar 5 Hasil Pengujian Decision Tree $\mathrm{J} 48$}

Pada Gambar 5 hasil pengujian menggunakan klasifikasi Decision Tree J48 memiliki tingkat accuracy sebesar 90,33\% atau 1608 instance yang menyatakan rasio prediksi benar dengan keseluruhan data testing yang diujikan, sedangkan mean absolute error sebesar 0,1297. Precision pada kelas Daftar 92,7\% menunjukkan bahwa persentase calon mahasiswa baru yang benar melakukan pendaftaran dari keseluruhan calon mahasiswa baru yang diprediksi melakukan pendaftaran. Kelas Tidak Daftar memiliki Precision sebesar $87,7 \%$ menunjukkan bahwa persentase calon mahasiswa baru yang benar tidak melakukan pendaftaran dari keseluruhan calon mahasiswa baru mahasiswa yang diprediksi tidak melakukan pendaftaran.

Recall untuk kelas Daftar sebesar 89,5\% menunjukkan bahwa persentase calon mahasiswa baru yang diprediksi melakukan pendaftaran dibandingkan keseluruhan calon mahasiswa baru yang sebenarnya melakukan pendaftaran. Sedangkan Recall untuk kelas Tidak daftar sebesar 91,4\% menunjukkan bahwa persentase calon mahasiswa baru yang diprediksi tidak melakukan pendaftaran dibandingkan keseluruhan calon mahasiswa baru yang sebenarnya tidak melakukan pendaftaran.

Confusion Matrix Decision Tree J48, baris pertama terdapat "874 103" menunjukkan bahwa ada instance class Daftar dalam data testing diantaranya 874 benar di prediksi sebagai Daftar dan 103 salah diklasifikasikan sebagai Tidak Daftar. 
Pada Baris kedua terdapat "69 734" menunjukkan bahwa ada instance class Tidak Daftar dalam data testing diantaranya 69 salah diklasifikasi sebagai Daftar dan 734 benar diklasifikasikan Tidak Daftar.

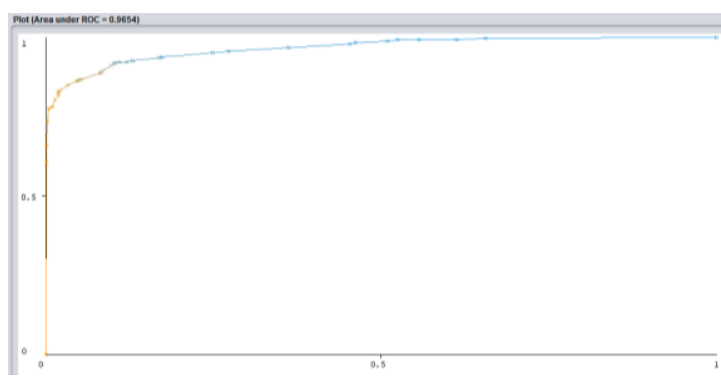

\section{Gambar 6 Area Under ROC Decision} Tree $\mathrm{J} 48$

Gambar 6 menunjukkan Area Under ROC dihitung untuk mengukur perbedaan performansi. Berdasarkan hasil pengujian menggunakan pengukuran Decision Tree J48 didapatkan hasil AUROC 0,9654.

Gambar 7 menunjukkan hasil prediksi terhadap data testing sebanyak 1780 record setelah model dibentuk menggunakan klasifikasi Decision Tree J48. Sedangkan Waktu yang dibutuhkan dalam test model selama 0,05 detik.

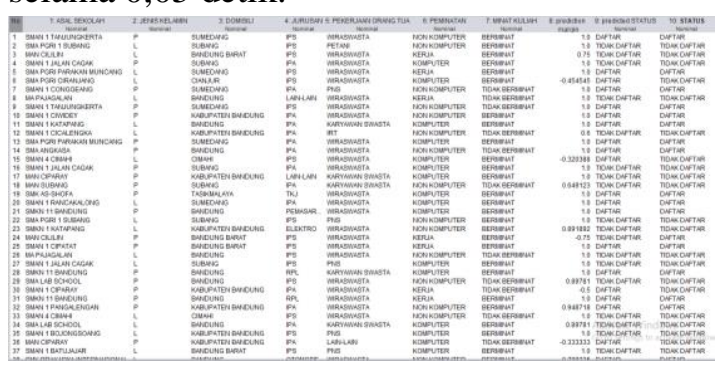

\section{Gambar 7 Hasil Prediksi Klasifikasi} Decision Tree J48.

\section{c. K-Nearest Neighbor}

Gambar 8 merupakan hasil pengujian klasifikasi K-Nearest Neighbor terhadap data training, pengujian dilakukan dengan metode yang sama pada Nä̈ve Bayes dan Decision Tree J48.

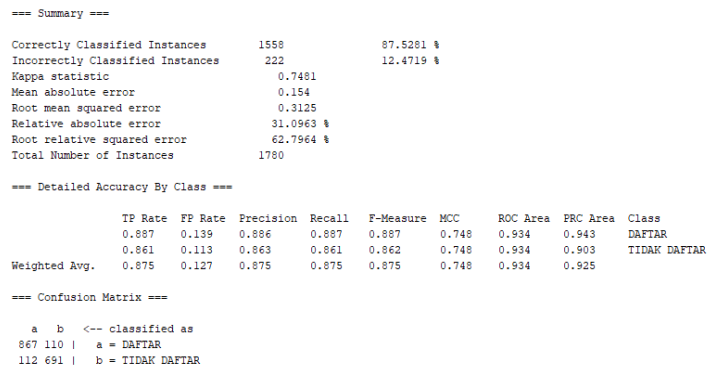

\section{Gambar 8 Hasil Pengujian K-Nearest Neighbor}

Pada Gambar 8 hasil pengujian menggunakan klasifikasi $K$-Nearest Neighbor memiliki tingkat accuracy sebesar $87,52 \%$ atau 1558 instance yang menyatakan rasio prediksi benar dengan keseluruhan data testing yang diujikan, sedangkan mean absolute error sebesar 0,154. Precision pada kelas Daftar 88,6\% menunjukkan bahwa persentase calon mahasiswa baru yang benar melakukan pendaftaran dari keseluruhan calon mahasiswa baru yang diprediksi melakukan pendaftaran. Kelas Tidak Daftar memiliki Precision sebesar 86,3\% menunjukkan bahwa persentase calon mahasiswa baru yang benar tidak melakukan pendaftaran dari keseluruhan calon mahasiswa baru mahasiswa yang diprediksi tidak melakukan pendaftaran.

Recall untuk kelas Daftar sebesar 88,7\% menunjukkan bahwa persentase calon mahasiswa baru yang diprediksi melakukan pendaftaran dibandingkan keseluruhan calon mahasiswa baru yang sebenarnya melakukan pendaftaran. Sedangkan Recall untuk kelas Tidak daftar sebesar $86,1 \%$ menunjukkan bahwa persentase calon mahasiswa baru yang diprediksi tidak melakukan pendaftaran dibandingkan keseluruhan calon mahasiswa baru yang sebenarnya tidak melakukan pendaftaran.

Confusion Matrix K-Nearest Neighbor, baris pertama terdapat "867 110" menunjukkan bahwa ada instance class Daftar dalam data testing diantaranya 867 benar di prediksi sebagai Daftar dan 110 
JURNAL NUANSA INFORMATIKA

Volume 15 Nomor 2, Juli 2021

salah diklasifikasikan sebagai Tidak Daftar. Pada Baris kedua terdapat "112 691" menunjukkan bahwa ada instance class Tidak Daftar dalam data testing diantaranya 112 salah diklasifikasi sebagai Daftar dan 691 benar diklasifikasikan Tidak Daftar.

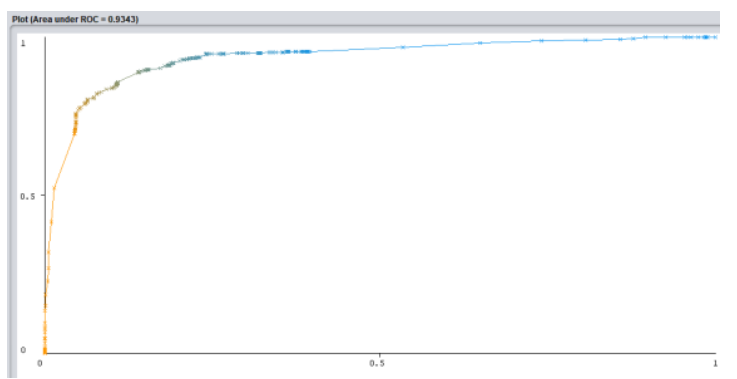

\section{Gambar 9 Area Under ROC K-Nearest Neighbor}

Gambar 9 menunjukkan Area Under $R O C$ dihitung untuk mengukur perbedaan performansi. Berdasarkan hasil pengujian menggunakan pengukuran $K$-Nearest Neighbor didapatkan hasil AUROC 0,9343.

Gambar 10 menunjukkan hasil prediksi terhadap data testing sebanyak 1780 record setelah model dibentuk menggunakan klasifikasi K-Nearest Neighbor. Sedangkan Waktu yang dibutuhkan dalam test model selama 1.2 detik.

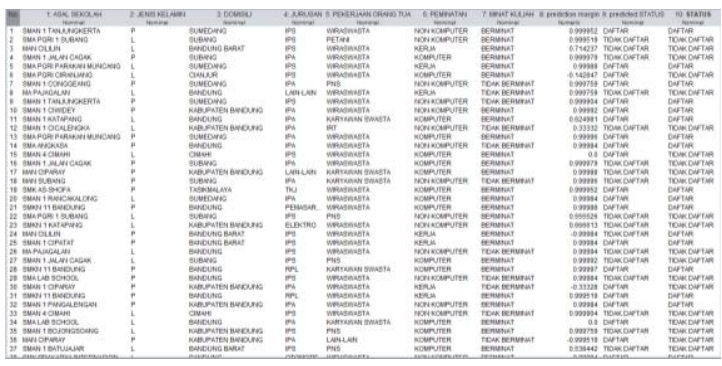

Gambar 10 Hasil Prediksi Klasifikasi $K$ Nearest Neighbor

\subsection{Fase Penyebaran (Deployment Phase)}

Perbandingan algoritma klasifikasi pada penelitian ini berdasarkan hasil output pada ketiga teknik klasifikasi yaitu Nä̈ve Bayes, Decision Tree J48 dan K-Nearest Neighbor menggunakan tools WEKA dengan mode split test terdiri dari $70 \%$ atau 4154 data
p-ISSN : 1858-3911, e-ISSN : 2614-5405

https://journal.uniku.ac.id/index.php/ilkom

sebagai data training dan $30 \%$ atau 1780 data sebagai data testing diantaranya Correctly Classified Instances, Incorrectly Classified Instances, Mean absolute error, Average Precision, Average Recall, FMeasure, Time taken to build model dan Time taken to test model on test split. Tabel 3 menunjukkan perbandingan kinerja pada masing-masing algoritma klasifikasi pada penelusuran potensi dan minat calon mahasiswa baru.

Tabel 3 Perbandingan Kinerja Algoritma Klasifikasi

\begin{tabular}{|c|c|c|c|c|}
\hline $\begin{array}{l}\text { Hasil } \\
\text { Penguji } \\
\text { an }\end{array}$ & NB & $\mathrm{J} 48$ & KNN & $\begin{array}{l}\text { Bai } \\
k\end{array}$ \\
\hline $\begin{array}{l}\text { Correctl } \\
y \\
\text { Classifie } \\
d \\
\text { Instance } \\
s\end{array}$ & $\begin{array}{l}87,24 \\
\%\end{array}$ & $\begin{array}{l}90,33 \\
\%\end{array}$ & $\begin{array}{l}87,52 \\
\%\end{array}$ & $\mathrm{~J} 48$ \\
\hline $\begin{array}{l}\text { Incorrec } \\
\text { tly } \\
\text { Classifie } \\
d \\
\text { Instance } \\
s\end{array}$ & $\begin{array}{l}12,76 \\
\%\end{array}$ & $\begin{array}{l}9,67 \\
\%\end{array}$ & $\begin{array}{l}12,48 \\
\%\end{array}$ & $\mathrm{~J} 48$ \\
\hline $\begin{array}{l}\text { Mean } \\
\text { absolute } \\
\text { error }\end{array}$ & $\begin{array}{l}0,166 \\
5\end{array}$ & $\begin{array}{l}0,129 \\
7\end{array}$ & 0,154 & $\mathrm{~J} 48$ \\
\hline $\begin{array}{l}\text { Average } \\
\text { Precisio } \\
n\end{array}$ & 0,878 & 0,904 & 0,875 & $\mathrm{~J} 48$ \\
\hline $\begin{array}{l}\text { Average } \\
\text { Recall }\end{array}$ & 0,872 & 0,903 & 0,875 & $\mathrm{~J} 48$ \\
\hline $\begin{array}{l}F- \\
\text { Measure }\end{array}$ & 0,873 & 0,904 & 0,875 & $\mathrm{~J} 48$ \\
\hline $\begin{array}{l}\text { Time } \\
\text { taken to } \\
\text { build } \\
\text { model }\end{array}$ & 0,02 & 0,09 & 0 & $\begin{array}{l}\mathrm{KN} \\
\mathrm{N}\end{array}$ \\
\hline $\begin{array}{l}\text { Time } \\
\text { taken to } \\
\text { test }\end{array}$ & 0,03 & 0,05 & 1,2 & NB \\
\hline
\end{tabular}




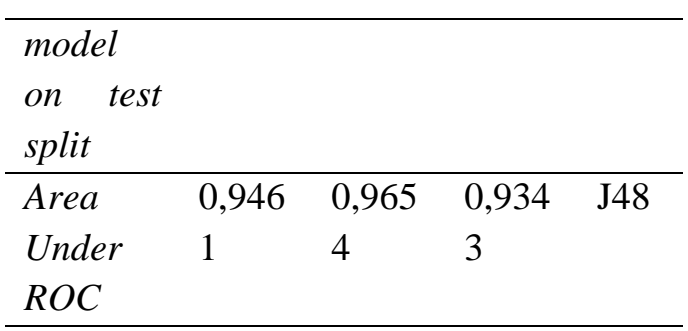

Accuracy klasifikasi secara umum dapat ditentukan berdasarkan Correctly Classified Instances. Pada gambar 11 menunjukkan perbandingan accuracy prediksi pada ketiga algoritma. Berdasarkan gambar 11 accuracy prediksi tertinggi adalah Decision Tree J48 dengan nilai accuracy sebesar 90,34\% sedangkan K-Nearest Neighbor nilai accuracy sebesar 87,53 dan Nä̈ve Bayes nilai accuracy sebesar $87,25 \%$. Hal ini menunjukkan bahwa Decision Tree J48 merupakan algoritma yang lebih baik dari sisi accuracy prediksi dibandingkan Nä̈ve Bayes dan K-Nearest Neighbor terhadap data set. Semakin tinggi nilai accuracy prediksi maka model klasifikasi semakin baik.

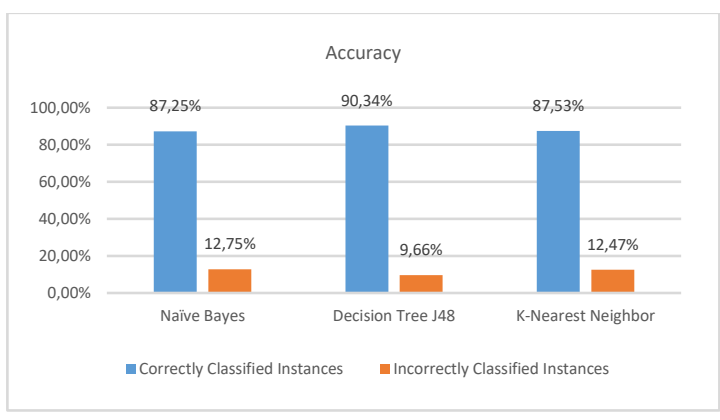

\section{Gambar 11 Grafik Perbandingan Correctly Classified Instances.}

Pada gambar 12 merupakan grafik perbandingan mean absolute error untuk ketiga algoritma. Berdasarkan gambar 12 algoritma Decision Tree J48 memiliki nilai mean absolute error paling rendah yaitu sebesar 0,1297 dibandingkan $K$-Nearest Neighbor yang memiliki nilai sebesar 0,154 dan Nä̈ve Bayes yang memiliki nilai sebesar 0,1665 . Semakin kecil nilai mean absolute error maka model klasifikasi semakin baik.

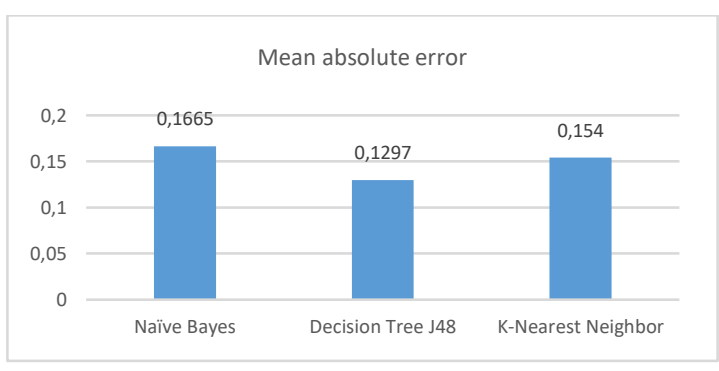

\section{Gambar 12 Grafik Perbandingan Mean} Absolute Error

Pada gambar 13 merupakan grafik perbandingan Average Precision pada kelas Daftar dan Tidak Daftar, hal ini menunjukkan bahwa rata-rata persentase calon mahasiswa baru yang benar melakukan pendaftaran dari keseluruhan calon mahasiswa baru yang diprediksi melakukan pendaftaran dan persentase calon mahasiswa baru yang benar tidak melakukan pendaftaran dari keseluruhan calon mahasiswa baru mahasiswa yang diprediksi tidak melakukan pendaftaran. Berdasarkan gambar 13 terlihat bahwa perbandingan ratarata Precision tertinggi pada Decision Tree J48 sebesar 0,904 sedangkan Nä̈ve Bayes sebesar 0,878 dan K-Nearest Neighbor sebesar 0,875. Semakin tinggi nilai Precision maka model klasifikasi semakin baik.

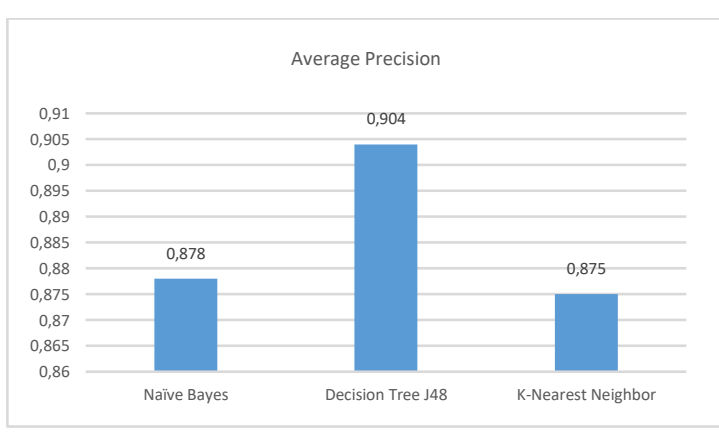

\section{Gambar 13 Grafik Perbandingan Average Precision}

Pada gambar 15 merupakan grafik perbandingan Average Recall untuk kelas Daftar yang menunjukkan bahwa persentase calon mahasiswa baru yang diprediksi melakukan pendaftaran dibandingkan keseluruhan calon mahasiswa baru yang 
sebenarnya melakukan pendaftaran dan Recall untuk kelas Tidak Daftar yang menunjukkan bahwa persentase calon mahasiswa baru yang diprediksi tidak melakukan pendaftaran dibandingkan keseluruhan calon mahasiswa baru yang sebenarnya tidak melakukan pendaftaran. Berdasarkan gambar 15 terlihat perbandingan Average Recall nilai tertinggi pada Decision Tree J48 sebesar 0,903 sedangkan K-Nearest Neighbor sebesar 0,875 dan Naïve Bayes sebesar 0,872. Semakin tinggi Average Recall nilai maka model klasifikasi semakin baik.

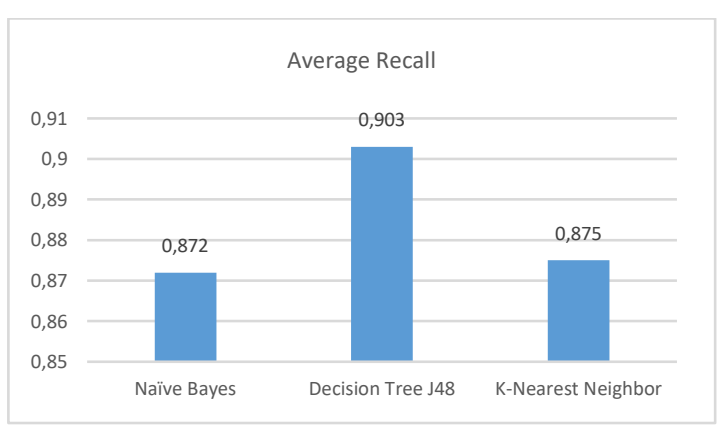

\section{Gambar 14 Grafik Perbandingan Average Recall}

Pada gambar 15 merupakan grafik perbandingan waktu yang dibutuhkan dalam membentuk model pada data training dalam satuan detik. Berdasarkan gambar 15 terlihat perbandingan waktu yang dibutuhkan $K$ Nearest Neighbor paling rendah yaitu 0 detik sedangkan Nä̈ve Bayes membutuhkan waktu 0,02 dan Decision Tree J48 membutuhkan waktu 0,09 detik. Semakin rendah waktu yang dibutuhkan maka model semakin baik.

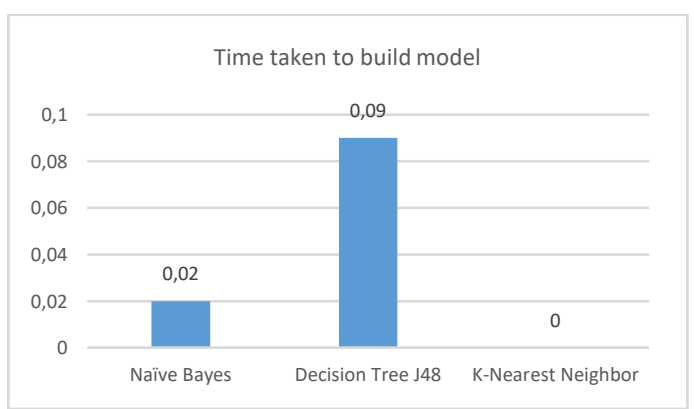

\section{Gambar 15 Grafik Perbandingan Time taken to build model}

Pada gambar 16 merupakan grafik perbandingan waktu yang dibutuhkan dalam melakukan pengujian data testing pada model yang telah terbentuk dalam satuan detik. Berdasarkan gambar 16 terlihat perbandingan waktu yang dibutuhkan dalam pengujian Nä̈ve Bayes paling rendah yaitu 0,03 detik sedangkan Decision Tree J48 membutuhkan waktu 0,05 dan $K$-Nearest Neighbor membutuhkan waktu 1,2 detik. Semakin rendah waktu yang dibutuhkan maka model semakin baik.

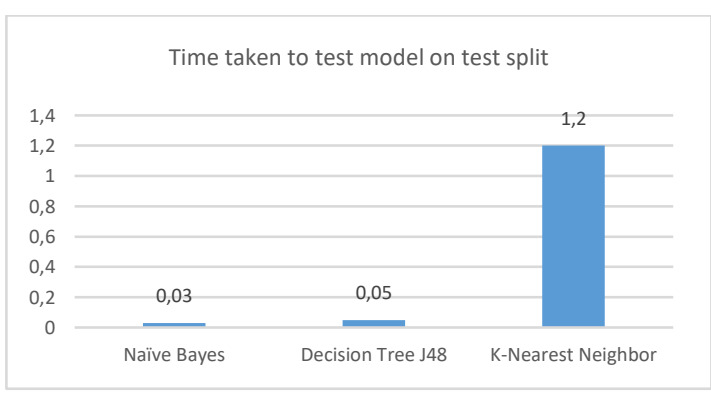

\section{Gambar 16 Grafik Perbandingan Time taken to test model on test split}

Pada gambar 17 merupakan grafik perbandingan Area Under ROC dihitung untuk mengukur perbedaan performansi. Berdasarkan gambar 17 terlihat perbandingan hasil pengujian menggunakan pengukuran Decision Tree J48 tertinggi yaitu 0,9654 sedangkan hasil pengujian menggunakan pengukuran Nä̈ve Bayes yaitu 0,9461 sedangkan dan hasil pengujian menggunakan pengukuran $K$-Nearest Neighbor yaitu 0,9343 .

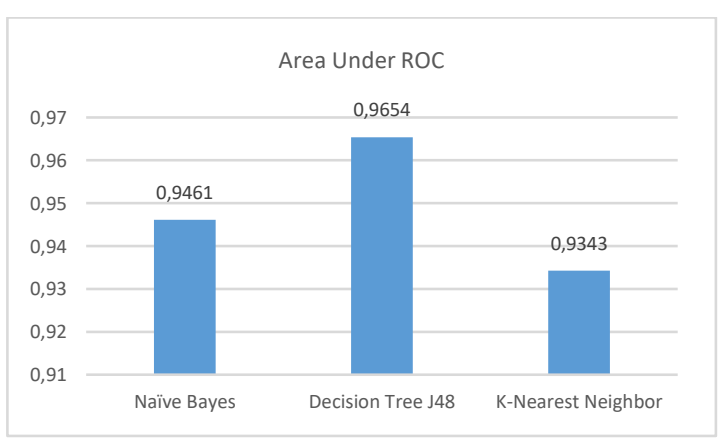


Gambar 17 Grafik Perbandingan Area Under ROC

Menurut Gorenescu untuk mengklasifikasikan keakuratan tes diagnosa pengujian menggunakan Area Under Curve dapat menggunakan tabel 4 dibawah ini:[19,20]

Tabel 4 Kriteria nilai AUC Nilai

\begin{tabular}{ll}
\hline Nilai AUC & Interpretasi \\
\hline $0,90-1,00$ & excellent classification \\
\hline $0,80-0,90$ & good classification \\
\hline $0,70-0,80$ & fair classification \\
\hline $0,60-0,70$ & poor classification \\
\hline $0,50-0,60$ & failure \\
\hline
\end{tabular}

Berdasarkan hasil pengujian dan panduan diatas, maka ketiga model masuk ke dalam kategori Excellent Classification. Semakin tinggi nilai Area Under ROC maka performansi model klasifikasi semakin baik.

Pada Gambar 18 merupakan grafik perbandingan hasil pengukuran accuracy $F$ Measure pada ketiga model klasifikasi. Berdasarkan gambar 18, perbandingan accuracy F-Measure tertinggi berada pada Decision Tree J48 dengan nilai 0,904 sedangkan K-Nearest Neighbor sebesar 0,875 dan Naïve Bayes sebesar 0,873. Semakin tinggi hasil pengukurun accuracy F-Measure maka model klasifikasi semakin baik.

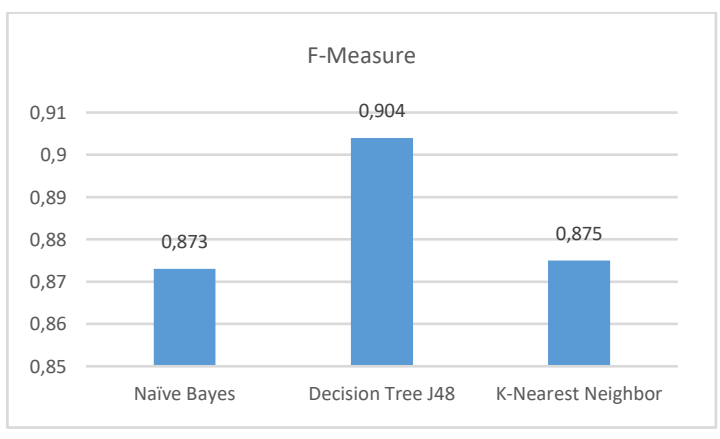

Gambar 18 Grafik Perbandingan $F$ Measure

\section{KESIMPULAN}

Penelitian ini dilakukan untuk
p-ISSN : 1858-3911, e-ISSN : 2614-5405

https://journal.uniku.ac.id/index.php/ilkom

menganalisa perbandingan algoritma klasifikasi data mining untuk penelusuran potensi dan minat calon mahasiswa baru. Berdasarkan hasil pengujian terhadap ketiga model algoritma klasifikasi diantaranya Nä̈ve Bayes, Decision Tree J48 dan $K$ Nearest Neighbor dengan menggunakan data set yang sama maka nilai accuracy tertinggi diperoleh pada klasifikasi Decision Tree J48 yang memperoleh nilai 90,3\% terdiri dari 1608 instance yang terklarifikasi benar dari 1780 data testing. Sedangkan klasifikasi K-Nearest Neighbor memiliki accuracy lebih rendah yaitu $87.52 \%$ terdiri dari 1558 instance yang terklarifikasi benar dari 1780 data testing dan klasifikasi Nä̈ve Bayes memiliki accuracy lebih rendah dari kedua klasifikasi yaitu $87.24 \%$ terdiri dari 1553 instance yang terklarifikasi benar dari 1780 data testing.

Perbandingan hasil pengujian Area Under Curve ROC, pengukuran Decision Tree J48 tertinggi yaitu 0,9654 sedangkan hasil pengujian menggunakan pengukuran Nä̈ve Bayes yaitu 0,9461 sedangkan dan hasil pengujian menggunakan pengukuran $K$-Nearest Neighbor yaitu 0,9343 . Ketiga klasifikasi memiliki nilai Area Under Curve diatas 0,90 masuk ke dalam kategori Excellent Classification. Semakin tinggi nilai Area Under ROC maka performansi model klasifikasi semakin baik.

Nilai mean absolute error pada klasifikasi Decision Tree J48 memiliki nilai lebih rendah dibandingkan klasifikasi Nä̈ve Bayes dan K-Nearest Neighbor yaitu 0,1297. Semakin kecil nilai mean absolute error maka model klasifikasi semakin baik. Hasil penelitian yang dilakukan dapat disimpulkan bahwa klasifikasi Decision Tree J48 dapat digunakan sebagai analisa oleh Bagian Marketing pada masa pandemi Covid-19. Hal ini diperkuat dengan hasil analisis perbandingan pada penelitian ini bahwa Decision Tree J48 mampu menganalisa penelusuran potensi dan minat calon 
mahasiswa baru yang melakukan pendaftaran dan tidak melakukan pendaftaran sebanyak 90,3\%.

\section{SARAN}

Untuk memperoleh hasil akurasi dan pola yang baik terhadap data set maka diperlukan penelitian lebih lanjut dengan penambahan algoritma klasifikasi yang lainnya sebagai perbandingan seperti Support Vector Machine, Random Forest dan lain-lain.

\section{UCAPAN TERIMA KASIH}

Peneliti mengucapkan terima kasih kepada Kementerian Pendidikan, Kebudayaan, Riset dan Teknologi yang telah memberikan kesempatan untuk melaksanakan penelitian pada skema Penelitian Dasar Pemula tahun pelaksanaan 2021 serta Lembaga Penelitian dan Pengabdian Masyarakat (LPPM) Universitas Informatika dan Bisnis Indonesia yang telah mendorong dan memfasilitasi setiap pelaksanaan penelitian..

\section{DAFTAR PUSTAKA}

[1] R. Setiawan, Aug. 2016, Penerapan Data Mining Menggunakan Algoritma K-Means Clustering untuk Menentukan Strategi Promosi Mahasiswa Baru (Studi Kasus : Politeknik Lp3i Jakarta), J. LENTERA ICT, vol. 3, no. 1, pp. 7692, Accessed: Feb. 25, 2021. [Online]. Available:

https://plj.ac.id/ojs/index.php/jrict/artic le/view/27.

[2] N. Yahya and A. Jananto, 2019, Komparasi Kinerja Algoritma C.45 dan Naive Bayes untuk Prediksi Kegiatan Penerimaan Mahasiswa Baru (Studi Kasus: Universitas STIKUBANK Semarang), in Prosiding SENDI_U, pp. 221-228, Accessed: Mar. 08, 2021. [Online]. Available: https://www.unisbank.ac.id/ojs/index.p hp/sendi_u/article/view/7389.
p-ISSN : 1858-3911, e-ISSN : 2614-5405

https://journal.uniku.ac.id/index.php/ilkom

[3] V. Raj and S. K. Manivannan, 2020, Predicting Student Failure in University Examination using Machine Learning Algorithms, Int. J. Innov. Technol. Explor. Eng., vol. 9, no. 5, pp. 956-959, doi: 10.35940/ijitee.E2643.039520.

[4] E. A. Baruah, S. Baruah, and J. Goswami, 2020, A Comparative Analysis of Different Classification Algorithms based on Students' Academic Performance Using WEKA, IOSR J. Comput. Eng., vol. 22, no. 1, pp. 49-56, doi: 10.9790/06612201024956.

[5] Nidhi, M. Kumar, N. Nayar, and G. Mehta, 2020, Student's Academic Performance Prediction in Academic using Data Mining Techniques, in 1st International Conference on Intelligent Communication and Computational Research (ICICCR-2020), pp. 1-5, Accessed: Mar. 08, 2021. [Online]. Available: https://ssrn.com/abstract=3565874.

[6] S. Widaningsih, Apr. 2019, Komparasi Kinerja Algoritma C.45 dan Naive Bayes untuk Prediksi Kegiatan Penerimaan Mahasiswa Baru (Studi Kasus: Universitas STIKUBANK Semarang), J. Tekno Insentif, vol. 13, no. $1, \quad$ pp. 16-25, doi: 10.36787/jti.v13i1.78.

[7] A. Azahari, Y. Yulindawati, D. Rosita, and S. Mallala, May 2020, Komparasi Data Mining Naive Bayes dan Neural Network memprediksi Masa Studi Mahasiswa S1, J. Teknol. Inf. dan Ilmu Komput., vol. 7, no. 3, pp. 443-452, doi: 10.25126/jtiik.2020732093.

[8] S. Linawati, R. A. Safitri, A. R. Alfiyan, W. E. Pangesti, and M. N. Winnarto, Mar. 2020, Perbandingan Algoritma Klasifikasi Naive Bayes dan SVM Pada Studi Kasus Pemberian Penerima Beasiswa PPA, Swabumi, vol. 8, no. 1, pp. 71-75, doi: 
10.31294/swabumi.v8i1.7708.

[9] Hermanto, A. Mustopa, and A. Y. Kuntoro, Feb. 2020, Algoritma Klasifikasi Naive Bayes dan Support Vector Machine dalam Layanan Komplain Mahasiswa, JITK (Jurnal Ilmu Pengetah. dan Teknol. Komputer), vol. 5, no. 2, pp. 211-220, doi: 10.33480/jitk.v5i2.1181.

[10] B. Budiman, R. Nursyanti, R. Y. R. Alamsyah, and I. Akbar, Sep. 2020, Data Mining Implementation Using Naïve Bayes Algorithm and Decision Tree J48 In Determining Concentration Selection, Int. J. Quant. Res. Model., vol. 1, no. 3, pp. 123-134, doi: 10.46336/ijqrm.v1i3.72.

[11] D. T. Larose and C. D. Larose, 2015, Data Mining and Predictive Analytics. Hoboken, New Jersey: John Wiley \& Sons, Inc.

[12] E. Sabna and M. Muhardi, 2016, Penerapan Data Mining Untuk Memprediksi Prestasi Akademik Mahasiswa Berdasarkan Dosen, Motivasi, Kedisiplinan, Ekonomi, dan Hasil Belajar, J. CoreIT J. Has. Penelit. Ilmu Komput. dan Teknol. Inf., vol. 2, no. 2, p. 41, doi: 10.24014/coreit.v2i2.2392.

[13] D. Astuti, A. R. Iskandar, and A. Febrianti, May 2019, Penentuan Strategi Promosi Usaha Mikro Kecil Dan Menengah (UMKM) Menggunakan Metode CRISP-DM dengan Algoritma K-Means Clustering, J. Informatics, Inf. Syst. Softw. Eng. Appl., vol. 1, no. 2, pp. 60-72, doi: 10.20895/inista.v1i2.71.

[14] P. Hari Santoso, May 2020, Application of Data Mining Classification for Covid-19 Infected Status Using Algortima Naïve Method, J. Mantik, vol. 4, no. 36, pp. 267-275, Accessed: Apr. 11, 2021. [Online]. Available: https://iocscience.org/ejournal/index.p
p-ISSN : 1858-3911, e-ISSN : 2614-5405

https://journal.uniku.ac.id/index.php/ilkom

hp/mantik/index.

[15] M. F. Maulana and M. Defriani, Mar. 2020, Logistic Model Tree and Decision Tree J48 Algorithms for Predicting the Length of Study Period, PIKSEL Penelit. Ilmu Komput. Sist. Embed. Log., vol. 8, no. 1, pp. 39-48, doi: 10.33558/piksel.v8i1.2018.

[16] S. Khruahong and P. Tadkerd, Oct. 2020, Analysis of Scholarship Consideration Using J48 Decision Tree Algorithm for Data Mining, in International Conference on Cooperative Design, Visualization and Engineering, vol. 12341, pp. 230-238, doi: 10.1007/978-3-030-60816-3_26.

[17] M. Kück and M. Freitag, Jan. 2021, Forecasting of Customer Demands for Production Planning by Local KNearest Neighbor Models, Int. J. Prod. Econ., vol. 231, p. 107837, doi: 10.1016/j.ijpe.2020.107837.

[18] H. Tang et al., 2020, Predicting Green Consumption Behaviors of Students Using Efficient Firefly Grey WolfAssisted K-Nearest Neighbor Classifiers, IEEE Access, vol. 8, pp. 35546-35562, doi: 10.1109/ACCESS.2020.2973763.

[19] F. Gorunescu, 2011, Data Mining: Concepts, Models and Techniques. Berlin: Springer-Verlag Berlin Heidelberg.

[20] Suwarno and A. Abdillah, 2016, Penerapan Algoritma Bayesian Regularization Backpropagation Untuk Memprediksi Penyakit Diabetes, $J$. MIPA, vol. 39, no. 2, pp. 150-158, Accessed: Mar. 16, 2021. [Online]. Available: http://journal.unnes.ac.id/nju/index.php /JM. 